\title{
PREFERENSI KONSUMEN TERHADAP DAGING AYAM BROILER DI ERA NEW NORMAL
}

\author{
(Consumer Preferences For Broiler Chicken In The New Normal Era) \\ Danang Priyambodo ${ }^{1}$, Intani Dewi ${ }^{2}$, Gilang Ayuningtyas ${ }^{3}$ \\ ${ }^{1}$ Program Studi Teknologi dan Manajemen Ternak, Sekolah Vokasi IPB \\ 2 Program Studi Manajemen Agribisnis, Sekolah Vokasi IPB \\ ${ }^{3}$ Program Studi Teknologi dan Manajemen Ternak, Sekolah Vokasi IPB \\ E-mail : danangpriyambodo@apps.ipb.ac.id
}

\begin{abstract}
Broiler chicken is one of poultry commodity which is consumed by many Indonesian people. In the buying process, there are several consumers who buy chicken meat in frozen form and in fresh form. The COVID-19 pandemic has forced most people to buy frozen broiler chicken. The aims of this study were to determine consumer attitudes towards the attributes of fresh and frozen chicken meat and to analyse the factors that influence consumers in purchasing decisions of fresh and frozen chicken meat in Bogor City at the new normal era. The research was carried out for 3 months, from October to December 2020. The sample of respondents in the study was determined intentionally (purposive sampling) as many as 250 respondents and the data collection technique used is survey method through direct interviews using questionnaires. The analytical method used are descriptive and multi-attribute Fishbein analysis. The factors that influence the purchase of broiler chicken with the highest average score (4.42) are based on health factor. Based on Fishbein's attitude model theory, the highest average value $(A o)$ found in fresh meat products, which means that respondents in the city of Bogor in the new normal era prefer fresh chicken meat products to frozen chicken meat products.
\end{abstract}

Key words: Broiler meat, Fishbein model, consumer preferences 


\section{PENDAHULUAN}

Ayam broiler merupakan komoditas ternak yang paling banyak dikonsumsi dagingnya oleh masyarakat Indonesia. Selain harga yang terjangkau dan mudah didapatkan, daging ayam broiler memiliki kandungan gizi protein hewani yang baik untuk pertumbuhan serta meningkatkan kecerdasan masyarakat. Kontribusi daging ayam broiler pada tahun 2019 dalam pemenuhan kebutuhan daging di tingkat nasional adalah sebesar 71,49\% (Ditjen PKH, 2020). Angka ini diperkirakan akan semakin meningkat seiring dengan bertambahnya jumlah penduduk Indonesia. Direkotrat Jenderal Peternakan dan Kesehatan Hewan Kementerian Pertanian Republik Indonesia (2020) menyatakan bahwa produksi daging ayam broiler pada tahun 2018 sebesar 3,4 juta ton dan tahun 2019 meningkat sebesar 3,5 juta ton. Hal ini menjadikan industri perunggasan di Indonesia memiliki prospek yang baik ke depannya.

Meningkatnya permintaan akan daging ayam broiler, mendorong beberapa perusahaan peternakan dan peternakan rakyat untuk memproduksi ayam broiler dalam jumlah yang banyak. Namun produksi yang banyak ini tidak setiap waktu selalu terserap di tingkat konsumen. Pada masa Pandemi Covid 19 beberapa waktu lalu, daya beli masyarakat secara umum menurun drastis termasuk dalam membeli daging ayam broiler. Hal ini menyebabkan banyak daging ayam yang tidak laku dipasar, sehingga harga ayam broiler saat itu juga ikut turun. Dikutip dari Kompas.com (2020), Pemerintah mengakui daya beli masyarakat saat ini melemah karena pendapatannya menurun. Penurunan pendapatan ini salah satunya akibat pemutusan hubungan kerja (PHK) sebagai dampak pandemi Covid-19. Selain itu kutipan lain dari Tempo.CO (2020) mengatakan wabah corona membuat permintaan ayam potong (broiler) turun drastis karena banyaknya hotel, restoran dan rumah makan yang tutup.

Pasar tradisional secara langsung mendapatkan efek dari hal tersebut karena menjual daging ayam segar. Ayam segar yang tidak laku di hari itu, maka tidak akan bisa dijual kembali pada hari berikutnya. Sedangkan pasar modern meskipun ikut terdampak penurunan harga ayam, namun produk yang tidak laku di hari tersebut masih bisa dijual untuk hari berikutnya karena menjual daging ayam dalam kondisi beku.

Semenjak masa pandemi Covid 19, terjadi juga perubahan perilaku konsumen yang biasanya membeli produk segar menjadi produk beku. Hal ini karena masyarakat sebagian besar melakukan aktivitasnya dirumah termasuk belanja kebutuhan pangan secara online. Pembelian bahan pangan seperti daging ayam sebagian besar dibeli dalam bentuk daging beku karena sebagian besar pasar online menjual daging ayam dalam kondisi beku. Akan tetapi, beberapa masyarakat tetap ada yang memilih daging ayam segar untuk dikonsumsi dengan beberapa alasan salah satu diantaranya masih baru (hangat). Kondisi seperti ini yang membuat pedagang di pasar tradisional pada masa pandemi Covid 19 tetap masih banyak yang menjual daging ayam segar. Berdasarkan hal tersebut, akibat dari menurunnya daya beli masyarakat maka banyak daging ayam segar yang tidak laku di pasar tradisional sehingga harga ayam ditingkat peternak dan di pasar turun cukup tinggi. 
Pada masa normal baru atau new normal diharapkan semua kondisi sudah mulai membaik, termasuk dalam hal daya beli masyarakat terhadap daging ayam broiler. Keputusan pembelian terhadap suatu produk sangat dipengaruhi oleh perilaku konsumen. Konsumen biasanya membeli daging ayam broiler di pasar modern dalam bentuk beku dan membeli di pasar tradisional dalam bentuk segar atau hangat. Setiap konsumen dalam memilih produk yang akan dibeli selalu memperhatikan beberapa atribut atau karakteristik yang melekat pada produk tersebut sebagai pertimbangan dalam memutuskan membeli produk tersebut. Menurut Sumarwan (2004), perilaku konsumen akan sangat terkait dengan atribut produk. Daging ayam segar dan beku memiliki karakteristik yang berbeda, hal ini sangat mempengaruhi keputusan konsumen dalam membeli daging segar atau daging beku. Setiap konsumen menginginkan daging ayam sesuai dengan preferensinya dan melalui pengamatan beberapa atribut yang terdapat pada daging ayam tersebut baik segar maupun beku.

Preferensi konsumen terhadap daging ayam broiler di masa new normal penting diketahui untuk lebih memahami perilaku konsumen. Pada masa new normal, perlu diketahui apakah konsumen tetap banyak yang membeli daging ayam beku dengan beberapa atribut pemilihaannya atau banyak konsumen yang kembali memilih daging ayam segar dengan berbagai atributnya.

Tujuan dari Penelitian ini adalah mengetahui sikap konsumen terhadap daging ayam segar dan daging ayam beku dari berbagai atribut. Tujuan selanjutnya yaitu menganalisis faktor-faktor yang mempengaruhi konsumen dalam keputusan pembelian daging ayam segar dan daging ayam beku di kota Bogor pada era kebiasaan baru atau new normal.

\section{METODE PENELITIAN}

\section{Teknik, Waktu, dan Tempat Penelitian}

Metode yang digunakan dalam penelitian ini adalah metode survey menggunakan kuisioner sebagai alat pengumpul data dan dilakukan dengan Teknik wawancara kepada responden. Penelitian ini dilaksanakan di Kota Bogor Jawa Barat dengan pengambilan sampel di Prima Fresh Mart (Pasar modern), pasar tradisional, tempat penjualan ayam segar di sekitar Kota Bogor. Penelitian dilaksanakan selama 3 bulan yaitu mulai Oktober-Desember 2020.

\section{Penentuan Sampel Responden}

Sampel responden diambil menggunakan metode purposive sampling. Penelitian ini dilakukan pada konsumen yang memenuhi kriteria sebagai berikut: 1) berusia lebih dari 15 tahun; 2) responden adalah konsumen yang sudah pernah membeli daging ayam segar dan daging ayam beku. Responden yang dipilih harus memenuhi kriteria yang ditentukan karena mampu memberikan penilaian terhadap atribut atau karakteristik daging ayam segar dan daging ayam beku. Penarikan sampel dalam penelitian ini ditetapkan sebanyak 250 responden yang tersebar di beberapa lokasi penelitian. 


\section{Analisis Data}

Analisis data yang digunakan adalah analisis deskriptif dan analisis sikap multiatribut fishbein. Analisis deskriptif digunakan untuk mengolah informasi dan data yang berasal dari responden. Metode analisis fishbein digunakan untuk menganalisis sikap dan preferensi konsumen berdasarkan atribut produk daging ayam. Hasil analisis tersebut selanjutnya digunakan untuk mengkaji preferensi konsumen terhadap produk daging ayam. Model sikap multiatribut fishbein juga dapat digunakan untuk mengetahui hubungan antara pengetahuan produk yang dimiliki konsumen dengan sikap terhadap produk berkenaan dengan ciri atau atribut produk. Persamaan matematis dari model multiatribut fishbein Menurut Engel et al. (1995) adalah sebagai berikut :

Dimana:

$$
A o=\sum_{i=1}^{n} b i . e i
$$

Ao= Sikap terhadap objek

$\mathrm{bi}=$ Kekuatan kepercayaan bahwa objek memiliki atribut ke-i

$\mathrm{e}=$ Evaluasi mengenai atribut ke-i

$\mathrm{n}=$ Jumlah atribut yang menonjol

Penilaian dengan menggunakan analisis fishbein ini diambil dari perhitungan nilai rataan atribut yang terpilih oleh masing-masing responden kemudian diformulasikan ke dalam metode fishbein untuk menghasilkan nilai sikap konsumen $(A o)$ terhadap produk agribisnis apakah bersifat positif atau negatif. Komponen bi menggambarkan seberapa kuat konsumen percaya terhadap atribut produk daging ayam broiler. Kepercayaan biasanya diukur pada skala likert dengan 5 angka dari kemungkinan yang disadari dimulai dari sangat baik (5), baik (4), cukup baik (3), tidak baik (2) dan sangat tidak baik (1). Komponen ei menggambarkan evaluasi atribut produk daging ayam yang diukur secara khusus pada skala evaluasi 5 angka mulai dari sangat penting (5), penting (4), cukup penting (3), tidak penting (2) dan sangat tidak penting (1).

\section{HASIL DAN PEMBAHASAN}

\section{Profil Responden}

Responden dalam penelitian ini adalah konsumen yang biasa membeli daging ayam baik dalam kondisi segar atau dalam kondisi beku. Profil pengisi kuisioner dijelaskan berdasarkan usia, jenis kelamin, status pernikahan, pendidikan terakhir, pekerjaan, dan pendapatan rata-rata dalam 1 bulan. Pemilihan responden dilakukan dengan metode purposive sampling yaitu suatu metode dengan menetapkan ciri-ciri khusus kepada calon responden yang sesuai dengan tujuan penelitian sehingga diharapkan dapat menjawab permasalahan penelitian (Fatihudin, 2015). Menurut Setyaningsih et al. (2010), panel konsumen terdiri dari 30-100 orang tergantung pada target pemasaran suatu komoditi. 
Pengambilan sampel dilakukan dengan cara accidental sampling, yaitu pengambilan sampel yang dilakukan secara kebetulan (Maman, 2013).

Profil responden dilihat dari faktor usia yaitu paling tinggi berusia 38-48 tahun sebanyak 75 orang $(30 \%)$. Berdasarkan sebaran usia responden dapat dilihat bahwa mayoritas responden yang biasa membeli daging ayam berusia diatas 16 tahun sampai usia 48 tahun. Hal ini sesuai dengan pendapat Baraja (2018) yang menyatakan bahwa semakin dewasa individu akan mempengaruhi keputusan pembelian terhadap suatu produk menjadi lebih selektif dan disesuaikan dengan pola konsumsinya.

Jenis kelamin responden mayoritas perempuan $(61,2 \%)$. Umumnya perempuan didalam rumah tangga adalah orang yang menentukan dalam pemenuhan kebutuhan makanan keluarga, sehingga lebih banyak perempuan yang berbelanja bahan makanan untuk kebutuhan keluarganya. Hasil yang diperoleh ini sesuai dengan pendapat Wijayanti (2011) yang mengatakan bahwa perempuan cenderung memiliki peran yang lebih besar dalam rumah tangga, dan salah satunya dalam menyediakan konsumsi keluarga. Responden juga mayoritas sudah menikah (69\%). Hal ini menunjukkan bahwa sebagian besar pengambil keputusan membeli daging ayam broiler di masyarakat adalah ibu rumah tangga.

Berdasarkan tingkat pendidikan terakhir, dapat dilihat bahwa semua tingkat pendidikan terwakili dari responden dalam penelitian ini dan mayoritas responden yang melakukan pembelian daging ayam broiler adalah berpendidikan SMA (47\%). Pekerjaan responden didominasi sebagai ibu rumah tangga sebanyak 51 orang $(30,4 \%)$. Kotler dan Amstrong (2008) menjelaskan bahwa pekerjaan merupakan salah satu yang menjadi faktor seseorang dalam perilaku membeli. Hasil dari penelitian ini semakin dapat mencerminkan kondisi aktual yang terjadi di masyarakat yaitu ibu rumah tangga yang cenderung berbelanja kebutuhan rumah tangga termasuk kebutuhan untuk konsumsi makanan. Sebagian besar responden memiliki pendapatan bulannya kurang dari Rp. 1.000.000. Hasil yang diperoleh ini menunjukkan bahwa daging ayam broiler dapat dibeli oleh semua kalangan berdasarkan pendapatan perbulannya. Rincian profil responden disajikan pada Tabel 1.

Tabel 1 Profil Responden

\begin{tabular}{lcr}
\hline \multicolumn{1}{c}{ Kategori } & $\begin{array}{c}\text { Jumlah Responden } \\
\text { (orang) }\end{array}$ & Persentase (\%) \\
\hline Usia (tahun) & 9 & 3,6 \\
$<16$ & 49 & 19,6 \\
$16-26$ & 61 & 24,4 \\
$27-37$ & 75 & 30,0 \\
$38-48$ & 35 & 14,0 \\
$49-59$ & 21 & 8,4 \\
$>59$ & & \\
Jenis Kelamin & 97 & 38,8 \\
Laki-laki & 153 & 61,2 \\
Perempuan & & \\
Status Pernikahan & & \\
\hline
\end{tabular}




\begin{tabular}{lcc}
\hline \multicolumn{1}{c}{ Kategori } & $\begin{array}{c}\text { Jumlah Responden } \\
\text { (orang) }\end{array}$ & Persentase (\%) \\
\hline Belum menikah & 77 & 31,0 \\
Menikah & 173 & 69,0 \\
Pendidikan terakhir & & \\
SD & 40 & 16,0 \\
SMP & 35 & 14,0 \\
SMA & 118 & 47,0 \\
Diploma & 30 & 12,0 \\
S1 & 17 & 7,0 \\
S2/S3 & 10 & 4,0 \\
Pekerjaan & & \\
Pelajar & 76 & 20,4 \\
Ibu rumah tangga & 51 & 30,4 \\
Karyawan Swasta & 73 & 29,2 \\
Wirausaha & 33 & 13,2 \\
Guru & 2 & 0,8 \\
Pegawai Negeri Sipil & 10 & 4,0 \\
Buruh & 4 & 1,6 \\
Pensiunan & 1 & 0,4 \\
Pendapatan & 140 & \\
< Rp 1.000.000 & 50 & 56,0 \\
Rp 1.000.000 - Rp 3.000.000 & 35 & 20,0 \\
Rp 3.000.000 - Rp 5.000.000 & 25 & 14,0 \\
> Rp 5.000.000 & & 10,0 \\
\hline
\end{tabular}

\section{Tahapan Proses Keputusan Pembelian Daging Ayam Broiler}

Proses keputusan pembelian daging ayam broiler adalah tahapan yang dilakukan sebelum pembelian aktual sampai dampak yang dirasakan setelah mengkonsumsi daging ayam broiler. Sikap konsumen dalam memilih suatu produk tentunya diawali dengan ketertarikan secara fisik atau melihat beberapa atribut yang mengiringi produk tersebut. Adapun definisi atribut produk adalah pengembangan suatu produk atau jasa yang melibatkan penentuan manfaat yang akan diberikan (Kotler dan Amstrong, 2013).

Proses pengambilan keputusan suatu produk oleh konsumen terdiri dari lima tahapan yaitu tahap pengenalan kebutuhan, pencarian informasi, evaluasi alternatif, proses pembelian dan hasil atau perilaku pasca pembelian (Widiyanto et al. 2016). Pada tahap pengenalan kebutuhan, sebagain besar responden mengatakan motivasi terbesar dalam mengkonsumsi daging ayam adalah karena faktor kesehatan (44\%). Manfaat yang dicari responden dalam mengkonsumsi daging ayam adalah sebesar $63 \%$ menjawab sebagai menu makanan. Atribut dan persentase dalam tahap pengenalan kebutuhan dapat dilihat pada Tabel 2.

Tabel 2 Atribut dan persentase dalam pengenalan kebutuhan 


\begin{tabular}{clc}
\hline No & \multicolumn{1}{c}{ Atribut } & Persentase (\%) \\
\hline $\mathbf{1}$ & Motivasi & \\
& Kesehatan & 44,0 \\
& harga terjangkau & 24,0 \\
& Gaya hidup & 11,0 \\
& pengaruh keluarga & 11,0 \\
& Sekedar mencoba & 4,0 \\
& Lainnya (promosi) & 6,0 \\
$\mathbf{2}$ & Manafaat mengkonsumsi daging ayam & \\
& Menu makanan & 63,0 \\
& Memperoleh kesehatan & 21,0 \\
& Selingan makanan & 16,0 \\
\hline
\end{tabular}

Dalam proses pencarian informasi, hasil penelitian menunjukkan bahwa $65 \%$ responden menjawab informasi lokasi penjualan daging ayam broiler berasal dari keluarga. Selanjutnya mengenai informasi dari media sosial, sebanyak $73 \%$ responden menjawab media sosial mampu memengaruhi preferensi membeli daging ayam broiler. Media sosial yang sangat mempengaruhi preferensi konsumen dalam membeli daging ayam dinyatakan oleh responden sebanyak $39 \%$ yaitu Whatsapp (WA). Hasil yang diperoleh ini sangat menarik, karena manfaat media sosial dalam hal ini dapat membantu produsen daging ayam sebagai media promosi yang efektif. Selanjutnya sebanyak $66 \%$ responden menyatakan bahwa iklan dapat menarik perhatian responden dalam membeli daging ayam broiler, dan faktor terbesar dari iklan tersebut yang disampaikan responden sebanyak $65 \%$ adalah karena faktor harga. Responden akan tertarik dengan iklan yang memberikan informasi harga daging ayam broiler yang murah. Atribut dan persentase mengenai tahapan dalam pencarian informasi dapat dilihat pada Tabel 3.

Tabel 3 Atribut dan persentase dalam Pencarian Informasi

\begin{tabular}{clc}
\hline No & \multicolumn{1}{c}{ Atribut } & Persentase (\%) \\
\hline $\mathbf{1}$ & Informasi lokasi penjuala & \\
& Teman & 14,0 \\
& Keluarga & 65,0 \\
& Iklan & 8,0 \\
& Lainnya & 13,0 \\
2 & Jenis Media Sosial & \\
& Facebook & 22,0 \\
& Instagram & 24,0 \\
& WhatsApp & 39,0 \\
& Line & 15,0 \\
3 & Pengaruh Iklan & \\
& lya & 66,0 \\
& Tidak & 34,0 \\
4 & Perhatian pada iklan & \\
& Harga & 67,0 \\
\hline
\end{tabular}




\begin{tabular}{llc}
\hline No & Atribut & Persentase (\%) \\
\hline Kemasan & 6,0 \\
Berat & 5,0 \\
Promo & 8,0 \\
Lokasi penjualan & 7,0 \\
Lainnya & 7,0 \\
\hline
\end{tabular}

Pada tahap evaluasi alternatif, yang menjadi pertimbangan utama responden sebelum membeli daging ayam broiler adalah $65 \%$ menjawab karena faktor harga. Hal ini sesuai dengan pendapat Anwar (2015) yang menyatakan bahwa harga sebuah produk atau jasa merupakan faktor penentu dalam permintaan pasar. Selanjutnya hasil penelitian menunjukkan sebagian besar responden menyatakan produk daging ayam yang bermutu dapat dilihat dari harga dan tampilan produk yaitu masing-masing sebesar $32 \%$. Atribut dan persentase dalam tahapan evaluasi alternatif dapat dilihat pada Tabel 4 .

Tabel 4 Atribut dan persentase dalam evaluasi alternatif

\begin{tabular}{clc}
\hline No & \multicolumn{1}{c}{ Atribut } & Persentase (\%) \\
\hline $\mathbf{1}$ & Pertimbangan sebelum membeli & \\
& Harga & 65,0 \\
& Kemasan & 13,0 \\
& Berat & 7,0 \\
& Promo & 5,0 \\
& Lokasi penjualan & 6,0 \\
& Lainnya & 4,0 \\
2 & Produk Daging Ayam Yang Bermutu & \\
& Harga & 32,0 \\
& Lokasi Penjualan & 10,0 \\
& Merk terkenal & 12,0 \\
& Tampilan produk & 32,0 \\
& Kemasan & 5,0 \\
& Lainnya & 9,0 \\
\hline
\end{tabular}

Pengertian keputusan adalah seleksi terhadap dua pilihan alternatif atau lebih (Schiffman dan Kanuk, 2008). Pada tahap keputusan pembelian daging ayam broiler, sebagian besar responden melakukan pembelian secara terencana (52\%) dengan frekuensi pembelian daging ayam dalam seminggu sebanyak 2 kali $(38 \%)$. Adapun ukuran daging ayam broiler yang paling banyak dibeli adalah ukuran $0,5-1 \mathrm{~kg}(64 \%)$. Pratama et al. (2015) melaporkan bahwa konsumen di pasar tradisonal kota Denpasar menyukai karkas ayam berukuran $1,1-1,5 \mathrm{~kg}$. Hal ini menunjukkan bahwa di setiap daerah, pilihan masyarakat akan ukuran ayam berbeda-beda. Jenis daging ayam segar atau hangat lebih diminati oleh responden di kota Bogor sebesar $88 \%$. Hal ini menunjukkan bahwa di masa new normalpasca pandemic Covid 19, pembelian daging ayam dalam bentuk segar lebih dipilih oleh masyarakat dibandingkan daging beku. Sebagian besar reponden mengatakan memilih jenis daging ayam segar dibandingkan ayam beku adalah karena faktor 
harga (38\%). Mayoritas responden di era new normal membeli daging ayam broiler di pasar tradisional $(73 \%)$.

Pandemi Covid-19 yang mewabah ternyata tidak terlalu membawa perubahan besar bagi konsumen khususnya pada pembelian daging ayam broiler. Adapun perubahan tersebut hanya dialami $8 \%$ responden yang menyatakan terjadi perubahan pembelian melalui online dan mengurangi jumlah pembelian sesuai pendapatan yang dimiliki. Atribut dan persentase dalam tahapan keputusan pembelian dapat dilihat pada Tabel 5.

Tabel 5 Atribut dan persentase dalam keputusan pembelian

\begin{tabular}{|c|c|c|}
\hline No & Atribut & Persentase (\%) \\
\hline \multirow[t]{5}{*}{1} & Cara memutuskan pembelian & \\
\hline & Tergantung situasi & 32,0 \\
\hline & Mendadak & 15,0 \\
\hline & Terencana & 52,0 \\
\hline & Lainnya & 1,0 \\
\hline \multirow[t]{5}{*}{2} & Frekuensi Pembelian dalam 1 minggu & \\
\hline & 1 kali & 27,0 \\
\hline & 2 kali & 38,0 \\
\hline & 3 kali & 21,0 \\
\hline & Lebih dari 4 kali & 14,0 \\
\hline \multirow[t]{4}{*}{3} & Berat karkas & \\
\hline & $0,5-1 \mathrm{~kg}$ & 64,0 \\
\hline & $1-1,5 \mathrm{~kg}$ & 26,0 \\
\hline & Lebih dari $1,5 \mathrm{~kg}$ & 10,0 \\
\hline \multirow[t]{3}{*}{4} & Jenis Daging Ayam yang dibeli & \\
\hline & Ayam segar & 88,0 \\
\hline & Ayam beku & 12,0 \\
\hline \multirow[t]{7}{*}{5} & Alasan membeli daging ayam segar & \\
\hline & Harga & 38,0 \\
\hline & Label halal & 20,0 \\
\hline & Tampilan produk & 16,0 \\
\hline & Lokasi penjualan & 13,0 \\
\hline & Kemasan & 7,0 \\
\hline & Merk Terkenal & 6,0 \\
\hline \multirow[t]{4}{*}{6} & Lokasi Pembelian & \\
\hline & Pasar tradisional & 73,0 \\
\hline & Pasar modern & 15,0 \\
\hline & Online & 12,0 \\
\hline \multirow[t]{3}{*}{7} & Perubahan Pembelian pasca pandemi Covid 19 & \\
\hline & Ada & 8,0 \\
\hline & Tidak ada & 92,0 \\
\hline
\end{tabular}

Pada tahap evaluasi pasca pembelian, mayoritas responden, dalam penelitian ini menyatakan puas (97\%) terhadap daging ayam broiler yang dibeli. Besarnya tingkat kepuasan responden tersebut, maka perlu diketahui perilaku 
konsumen jika daging ayam broiler tidak tersedia untuk dibeli. Sebagian besar responden $(71 \%)$ menyatakan mencari ke tempat lain, dan Jika daging ayam broiler mengalami kenaikan harga, maka sikap responden sebagian besar akan tetap membeli (73\%). Atribut dan persentase dalam tahapan pasca pembelian dapat dilihat pada Tabel 6 .

Tabel 6 Atribut dan persentase dalam pasca pembelian

\begin{tabular}{clc}
\hline No & \multicolumn{1}{c}{ Atribut } & Persentase (\%) \\
\hline $\mathbf{1}$ & Kepuasan terhadap daging ayam yang dibeli & \\
& Puas & 97,0 \\
\multirow{2}{*}{$\mathbf{2}$} & Tidak puas & 3,0 \\
& Respon jika harga daging ayam naik & \\
& Akan membeli & 73,0 \\
& Tidak Membeli & 10,0 \\
& Membeli merk/jenis lain yang lebih murah & 16,0 \\
\multirow{2}{*}{3} & lainnya & 1,0 \\
& Respon jika tidak tersedia daging ayam & 71,0 \\
& Mencari ke tempat lain & 18,0 \\
& Tidak membeli & 11,0 \\
& Membeli daging lain & \\
\hline
\end{tabular}

\section{Analisis Multiatribut Fishbein}

\section{Faktor Yang Mempengaruhi Pembelian}

Menurut Schiffman dan Kanuk (1994), model sikap multiatribut fishbein dapat digunakan untuk mengukur sikap konsumen terhadap suatu produk atau jasa maupun merek spesifik. Untuk mengetahui faktor yang mempengaruhi pembelian suatu produk menggunakan metode Fishbein. Penelitian ini dilakukan secara preferensi yaitu responden diminta untuk menjawab beberapa pertanyaan berdasarkan pengalamannya dalam membeli dan mengkonsumsi olahan dari daging ayam broiler beku untuk memastikan dalam pemberian nilai dengan skala yang sudah ditentukan. Ketentuan angka penilaian yang diberikan yaitu $1=$ Sangat Tidak Penting, 2 = Tidak Penting, 3 = Biasa Saja, 4 = Penting, 5 = Sangat Penting . Setelah dilakukan penelitian secara preferensi, didapatkan hasil rata-rata nilai (ei) dari 250 responden. Faktor yang mempengaruhi pembelian daging beku disajikan pada Tabel 7.

Berdasarkan hasil yang terdapat pada Tabel 7 , diperoleh rata-rata nilai tertinggi $(4,42)$ dimiliki oleh atribut kesehatan. Hal ini menunujukkan bahwa tingkat kesehatan pada produk daging ayam beku yang akan dibeli untuk dikonsumsi sangat mempengaruhi dalam pembelian produk ayam beku. Di era new normal ini masyarakat percaya bahwa dengan membeli daging ayam beku, masyarakat akan mendapatkan daging yang lebih terjamin kesehatannya. Atribut selanjutnya yang dipilih yaitu pendapatan $(4,31)$, serta pengetahuan $(4,16)$. Sementara itu untuk nilai rata-rata terkecil berada pada atribut jenis kelamin $(3,09)$, yang artinya bahwa jenis kelamin untuk pembelian produk daging ayam broiler beku merupakan salah satu atribut yang kurang berpengaruh dalam pembelian ayam beku. Berdasarkan nilai 
yang diperoleh menunjukkan bahwa faktor yang mempengaruhi pembelian ayam berada pada skor di atas tiga yang artinya berada pada tingkat kepentingan yang cukup penting dan penting.

Tabel 7 Faktor yang mempengaruhi untuk pembelian produk daging ayam beku

\begin{tabular}{clc} 
No & \multicolumn{1}{c}{ Atribut } & Rata-rata \\
\hline 1 & Pendapatan & 4,31 \\
2 & Usia & 3,69 \\
3 & Jenis kelamin & 3,09 \\
4 & Pengetahuan & 4,16 \\
5 & Motivasi & 3,76 \\
6 & Teman / sahabat & 3,28 \\
7 & Keluarga & 4,00 \\
8 & Kesehatan & 4,42 \\
9 & Gaya hidup & 3,44 \\
10 & Kelas sosial & 3,13 \\
11 & Lingkungan & 3,23 \\
\hline
\end{tabular}

\section{Tingkat Kepentingan (ei)}

Tingkat kepentingan dalam hal ini disimbolkan dengan ei, berfungsi sebagai pengukur seberapa penting sebuah atribut bagi serorang konsumen dalam menilai sebuah produk. Berdasarkan hasil yang terdapat pada Tabel 8 , diperoleh rata-rata nilai $(e i)$ tertinggi dimiliki oleh atribut kehalalan $(1,93)$ dan kebersihan $(1,90)$. Hal ini menunjukkan di era new normal, responden yang berada di kota Bogor lebih mementingkan atribut kehalalan dan kebersihan pada produk ayam beku yang akan dibeli untuk dikonsumsi. Sementara itu untuk nilai rata-rata terkecil terdapat pada atribut iklan yang menarik $(0,77)$. Hal ini menandakan bahwa iklan yang menarik untuk pembelian produk ayam beku merupakan salah satu atribut yang kurang penting untuk diperhatikan. Tingkat kepentingan responden untuk produk ayam beku disajikan pada Tabel 8 .

Tabel 8 Rata-rata nilai (ei) untuk produk ayam beku

\begin{tabular}{|c|c|c|}
\hline No & Atribut & Rata - rata (ei) \\
\hline 1 & Rasa & 1,81 \\
\hline 2 & Warna & 1,84 \\
\hline 3 & Tekstur & 1,82 \\
\hline 4 & Aroma & 1,80 \\
\hline 5 & Ukuran & 1,28 \\
\hline 6 & Harga & 1,58 \\
\hline 7 & Kemasan & 1,36 \\
\hline 8 & Kebersihan produk & 1,90 \\
\hline 9 & Keamanan pangan & 1,86 \\
\hline 10 & Adanya diskon & 1,41 \\
\hline 11 & Kehalalan & 1,93 \\
\hline 12 & Tempat penjualan & 1,46 \\
\hline
\end{tabular}




\begin{tabular}{clc}
\hline No & \multicolumn{1}{c}{ Atribut } & Rata - rata $(\mathbf{e} \boldsymbol{i})$ \\
\hline 13 & Ketersediaan produk & 1,42 \\
14 & Daya Simpan produk & 1,66 \\
15 & Kemudahan mendapatkan & 1,43 \\
16 & Iklan yang menarik & 0,77 \\
\hline
\end{tabular}

\section{Tingkat Kepercayaan (bi)}

Setelah melakukan penilaian pada tingkat kepentingan (eI) untuk mengetahui nilai rata-rata dari responden yang berada di kota Bogor, langkah selanjutnya adalah melakukan penilaian tingkat kepercayaan pada atribut pada masing-masing produk ayam yaitu produk daging ayam broiler segar dan produk daging ayam broiler beku. Skala penilaian yang telah ditetapkan antara lain $-2=$ Sangat Tidak Penting, $-1=$ Tidak Penting, $0=$ Biasa Saja, $1=$ Penting, $2=$ Sangat Penting. Setelah dilakukan pengujian terhadap dua produk ayam untuk penilaian atribut, didapatkan rata-rata yang disajikan pada Tabel 9.

Jika dilihat pada hasil rata-rata penilaian dari dua buah produk ayam yang berbeda oleh 250 responden terhadap atributnya, responden sangat setuju dengan kehalalan produk dari ayam segar dan ayam beku. Hal ini ditunjukkan dengan tingkat kepercayaan sebesar 1,81 untuk ayam segar dan 1,53 untuk daging beku. Selanjutnya untuk nilai tertinggi kedua, tingkat kepercayaan pada ayam segar terdapat pada atribut rasa sebesar 1,68. Hal ini menunjukkan bahwa masyarakat percaya bahwa daging ayam segar memiliki rasa yang enak. Untuk daging beku, tingkat kepercayaan tertinggi kedua terdapat pada atribut kebersihan produk. Masyarakat percaya bahwa daging beku memiliki kebersihan yang baik. Atribut yang memiliki penilaian yang rendah dari responden yaitu atribut iklan yang menarik yang masing-masing memiliki tingkat kepercayaan 1,00 untuk daging ayam segar dan 0,93 untuk daging ayam beku.

Untuk daging ayam broiler beku, hasil rata-rata penilaian dari atribut yang ada sangat berbeda dengan penilaian dari produk daging ayam segar. Ayam beku nilai atributnya tidak ada yang melebihi ayam segar. Nilai rata-rata yang didapatkan menunjukkan bahwa di era new normal pasca pandemic covid 19, responden lebih percaya terhadap semua atribut yang dimiliki oleh daging ayam segar dibandingkan dengan daging ayam beku. Berdasarkan penilaian rata-rata tersebut menunjukkan bahwa responden cenderung lebih menyukai daging ayam segar dibandingkan dengan produk daging ayam beku dalam segala aspek berdasarkan perbandingan nilai atribut yang ada.

Tabel 9 Tingkat kepercayaan (bi) konsumen terhadap atribut produk Ayam

\begin{tabular}{clcc}
\hline No & Atribut & $\begin{array}{c}\text { Ayam } \\
\text { Segar }\end{array}$ & $\begin{array}{c}\text { Ayam } \\
\text { Beku }\end{array}$ \\
\hline 1 & Rasa & 1,68 & 1,22 \\
2 & Warna & 1,54 & 1,23 \\
3 & Tekstur & 1,51 & 1,20 \\
4 & Aroma & 1,42 & 1,16 \\
5 & Ukuran & 1,46 & 1,12 \\
\hline
\end{tabular}




\begin{tabular}{clcc}
\hline No & \multicolumn{1}{c}{ Atribut } & $\begin{array}{c}\text { Ayam } \\
\text { Segar }\end{array}$ & $\begin{array}{c}\text { Ayam } \\
\text { Beku }\end{array}$ \\
\hline 6 & Harga & 1,62 & 1,30 \\
7 & Kemasan & 1,50 & 1,35 \\
8 & Kebersihan produk & 1,60 & 1,40 \\
9 & Keamanan pangan & 1,63 & 1,39 \\
10 & Adanya diskon & 1,43 & 1,21 \\
11 & Kehalalan & 1,81 & 1,53 \\
12 & Tempat penjualan & 1,59 & 1,34 \\
13 & Ketersediaan produk & 1,52 & 1,25 \\
14 & Daya simpan produk & 1,56 & 1,38 \\
15 & Kemudahan mendapatkan & 1,51 & 1,22 \\
16 & Iklan yang menarik & 1,00 & 0,93 \\
\hline \multicolumn{2}{r}{ Rata-rata } & 1,52 & 1,26 \\
\hline
\end{tabular}

\section{Analisis Sikap Konsumen}

Sikap konsumen terjadi karena adanya pengenalan pada atribut dari sebuah produk. Dalam penelitian ini, sikap konsumen dilambangkan dengan lambang $(A o)$ yang merupakan hasil total dari perkalian antara tingkat kepercayaan (bi) dengan tingkat kepentingan (eI). Hasil dari sikap konsumen terhadap penilaian atribut produk ayam segar dan ayam beku disajikan pada Tabel 10.

Berdasarkan hasil pada Tabel 10 mengenai sikap konsumen (Ao) secara keseluruhan dari responden di kota Bogor terhadap seluruh atribut didapatkan nilai untuk produk ayam segar sebesar 65,01 dan untuk produk ayam beku dengan nilai 53,75. Dengan demikian berdasarkan teori model sikap Fishbein, rata-rata nilai $(A o)$ tertinggi adalah nilai yang diambil sebagai kesimpulan produk yang paling disukai dari responden di kota Bogor. Dapat dilihat pada Tabel 10, bahwa sikap konsumen di era new normal lebih menyukai produk daging ayam segar dibandingkan produk daging ayam beku untuk semua atribut yang diberikan.

Tabel 10 Sikap konsumen (Ao) terhadap atribut produk ayam segar dan ayam beku

\begin{tabular}{clcc}
\hline No & Atribut & $\begin{array}{c}\text { Ayam } \\
\text { Segar }\end{array}$ & $\begin{array}{c}\text { Ayam } \\
\text { Beku }\end{array}$ \\
\hline 1 & Rasa & 5,48 & 4,00 \\
2 & Warna & 5,21 & 4,15 \\
3 & Tekstur & 5,01 & 3,96 \\
4 & Aroma & 4,59 & 3,76 \\
5 & Ukuran & 2,40 & 1,84 \\
6 & Harga & 4,07 & 3,24 \\
7 & Kemasan & 2,77 & 2,50 \\
8 & Kebersihan produk & 5,78 & 5,06 \\
9 & Keamanan pangan & 5,66 & 4,82 \\
10 & Adanya diskon & 2,85 & 2,42 \\
11 & Kehalalan & 6,74 & 5,69
\end{tabular}




\begin{tabular}{|c|c|c|c|}
\hline No & Atribut & $\begin{array}{l}\text { Ayam } \\
\text { Segar }\end{array}$ & $\begin{array}{l}\text { Ayam } \\
\text { Beku }\end{array}$ \\
\hline 12 & Tempat penjualan & 3,38 & 2,86 \\
\hline 13 & Ketersediaan produk & 3,07 & 2,57 \\
\hline 14 & Daya simpan produk & 4,31 & 3,82 \\
\hline 15 & $\begin{array}{l}\text { Kemudahan } \\
\text { mendapatkan }\end{array}$ & 3,10 & 2,50 \\
\hline \multirow[t]{2}{*}{16} & Iklan yang menarik & 0,60 & 0,56 \\
\hline & Jumlah ei $\times$ bi & 65,01 & 53,75 \\
\hline
\end{tabular}

\section{SIMPULAN}

Preferensi konsumen terhadap daging ayam broiler di era new normal masih mengarah pada hal yang sangat baik dan kecenderungan daging ayam broiler masih menjadi pilihan utama responden. Pada kondisi pandemic covid-19 dan di era new normal dapat dilihat bahwa cara pembelian konsumen terhadap daging ayam broiler tidak jauh berbeda dan keputusan dalam membeli produk daging ayam tetap tinggi. Faktor yang mempengaruhi pembelian ayam dengan skor ratarata paling tinggi hingga paling rendah yaitu kesehatan $(4,42)$, pendapatan $(4,31)$, pengetahuan $(4,16)$, keluarga $(4,00)$, motivasi $(3,76)$, usia $(3,69)$, gaya hidup $(3,45)$, teman / Sahabat $(3,28)$, lingkungan $(3,23)$, kelas sosial $(3,13)$, jenis kelamin $(3,09)$. Berdasarkan teori model sikap Fishbein, rata - rata nilai $(A o)$ tertinggi terdapat pada produk daging segar yang artinya responden di kota Bogor di era new normal lebih memilih produk daging ayam segar dibandingkan produk daging ayam beku.

\section{DAFTAR PUSTAKA}

Anwar I. 2015. Pengaruh Harga Dan Kualitas Produk Terhadap Keputusan Pembelian. Jurnal IImu dan Riset Manajemen Vol. 4 (12)

Baraja RR. 2018. Analisis Persepsi dan Preferensi Konsumen terhadap Daging Sapi Beku di Maradeka Beef Bogor. [Skripsi]. Bogor : Institut Pertanian Bogor.

Direkorat Jenderal Peternakan dan Kesehatan Hewan. Statistik Peternakan 2020. Jakarta: Direkorat Jenderal Peternakan dan Kesehatan Hewan Kementerian Pertanian Republik Indonesia.

Engel JF, Blackwell RD, Miniard PW. 1995. Perilaku Konsumen Edisi Keenam. Volume ke 1 dan 2. Jakarta: Binarupa Aksara.

Fatihudin D. 2015. Metode Penelitian. Sidoarjo : Zifatama Publisher.

Kompas.com. Selasa 2 Oktober 2020. Dampak Pandemi Covid-19, Pemerintah Akui Daya Beli Masyarakat Melemah. Diakses 21 November 2020. https://money.kompas.com/read/2020/10/06/050800026/dampak-pandemicovid-19-pemerintah-akui-daya-beli-masyarakat-melemah.

Kotler P, Amstrong G. 2013. Prinsip-Prinsip Pemasaran Edisi Ketujuh. Jakarta: Erlangga. 
Kotler P, Amstrong G. 2008. Manajemen Pemasaran di Indonesia (Analisis, Perencanaan, Implementasi dan Pengendalian). Jakarta : Penerbit Selemba Empat

Maman P. 2013. Penentuan Jumlah dan Teknik Pengambilan Sampel untuk Sosial Ekonomi. Program Studi Sosial Ekonomi Peternakan. Fakultas Peternakan Universitas Padjadjaran. Bandung.

Pratama IGW, Sukanata IW, Parimartha IKW. 2015. Analisis Preferensi Konsumen dalam Membeli Daging Ayan Broiler di Pasar Tradisional Kota Denpasar. Journal of Tropical Animal Science 3 (3) : 549-560.

Schiffman L, Kanuk LL. 2008. Perilaku Konsumen. Jakarta : PT Indeks.

Schiffman LG, Kanuk LL. 1994. Consumer Behaviour. Prentice Hall, Inc., Englewood Cliffs, New Jersey.

Setyaningsih D, Apriyantono A, Sari MP. 2010. Analisis Sensori untuk Industri Pangan dan Agro. Bogor : IPB Press.

Sumarwan. 2004. Perilaku Konsumen, Teori, dan Penerapannya dalam Pemasaran. Jakarta: Ghalia Indonesia.

Tempo.Co. Selasa 21 April 2020. Harga Ayam Turun Akibat Corona, Peternak Minta Pemda Turun Tangan. Diakses 21 November 2020. https://bisnis.tempo.co/read/1334069/harga-ayam-turun-akibat-coronapeternak-minta-pemda-turun-tangan/full\&view=ok

Widiyanto NA, Andriyono KA, Heny KD. 2016. Atribut-Atribut yang Mempengaruhi Sikap dan Preferensi Konsumen dalam Membeli Buah Apel di Kota Surabaya dan Kota Malang, Provinsi Jawa Timur. Jurnal Ilmu Kel.\& Kons 136-146.

Wijayanti MR. 2011. Analisis Preferensi Konsumen dalam Membeli Daging Sapi di Pasar Tradisional Kabupaten Karanganyar. [Skripsi]. Surakarta: Universitas Sebelas Maret. 